Received $\quad 30.10 .2016$ Reviewed 01.12 .2016 Accepted 06.12.2016

A - study design

B - data collection

C - statistical analysis

D - data interpretation

$\mathbf{E}$ - manuscript preparation

F - literature search

\title{
Global experience on irrigation management under different scenarios
}

\author{
Mohammad VALIPOUR ${ }^{\text {ABCDEF } \bowtie}$
}

Islamic Azad University, Kermanshah Branch, Young Researchers and Elite Club, Imam Khomeini Campus, Farhikhtegan Bld. Shahid Jafari St., Kermanshah, Iran; e-mail: mohammad25mordad@yahoo.com

For citation: Valipour M. 2017. Global experience on irrigation management under different scenarios. Journal of Water and Land Development. No. 32 p. 95-102. DOI: 10.1515/jwld-2017-0011.

\begin{abstract}
This study aims to assess global experience on agricultural water management under different scenarios. The results showed that trend of permanent crops to cultivated area, human development index (HDI), irrigation water requirement, and percent of total cultivated area drained is increasing and trend of rural population to total population, total economically active population in agriculture to total economically active population, value added to gross domestic production $(G D P)$ by agriculture, and the difference between national rainfall index $(N R I)$ and irrigation water requirement is decreasing. The estimating of area equipped for irrigation in 2035 and 2060 were studied acc. to the three scenarios: I - the values of the main indices would be changed by the same slope of the past half of century, II and III - the slopes would be decreased by $30 \%$ and $50 \%$ respectively. The minimum and maximum values of pressure on renewable water resources by irrigation, are related to the third and first scenarios by $2035(6.1 \%)$ and $2060(9.2 \%)$, respectively.
\end{abstract}

Key words: irrigation, sustainable agriculture, water, world agriculture

\section{INTRODUCTION}

Due to limitation of water resources, role of macroeconomic policies in agricultural water management is vital and undeniable. According to the Figure 1a, b, value of renewable water resources per capita is decreasing (whether based on regions or based on incomes), while value of total people undernourished is steel considerable (Fig. 1c).

Therefore, pressure on renewable water resources is influenced due to demand for the food and applying irrigation systems to increase agricultural production. In the other hand, according to the Figure 2, total water withdrawal per capita has been decreased.

In Figure 2, agricultural indicates agricultural water withdrawal as percent of total water withdrawal $(\%)$, industrial indicates industrial water withdrawal as percent of total water withdrawal (\%), municipal indicates municipal water withdrawal as percent of total withdrawal $(\%)$, withdrawal indicates total water withdrawal per capita $\left(100 \mathrm{~m}^{3} \cdot\right.$ inhab $\left.^{-1} \cdot \mathrm{y}^{-1}\right)$, Managed indicates total agricultural water managed area to cultivated area $(\%)$, potential indicates percent of irrigation potential equipped for irrigation $(\%)$, value of these parameters are not available before 1977 .

Although agricultural water withdrawal as percent of total water withdrawal has been decreased due to industries and population growth as well as applying pressurized irrigation and management strategies to increase of efficiency, but more than $40 \%$ of irrigation potential is not developed yet.

As a result, the most pressure on renewable water resources is related to the agricultural sector and irrigation has the maximum water withdrawal in agriculture. Hence, the increase of pressure on renewable water resources by irrigation is possible and important in the future.

Although actual crop yield as percentage of potential yield is more than $60 \%$ for North America, and Western and Central Europe, it is less than $50 \%$ for 

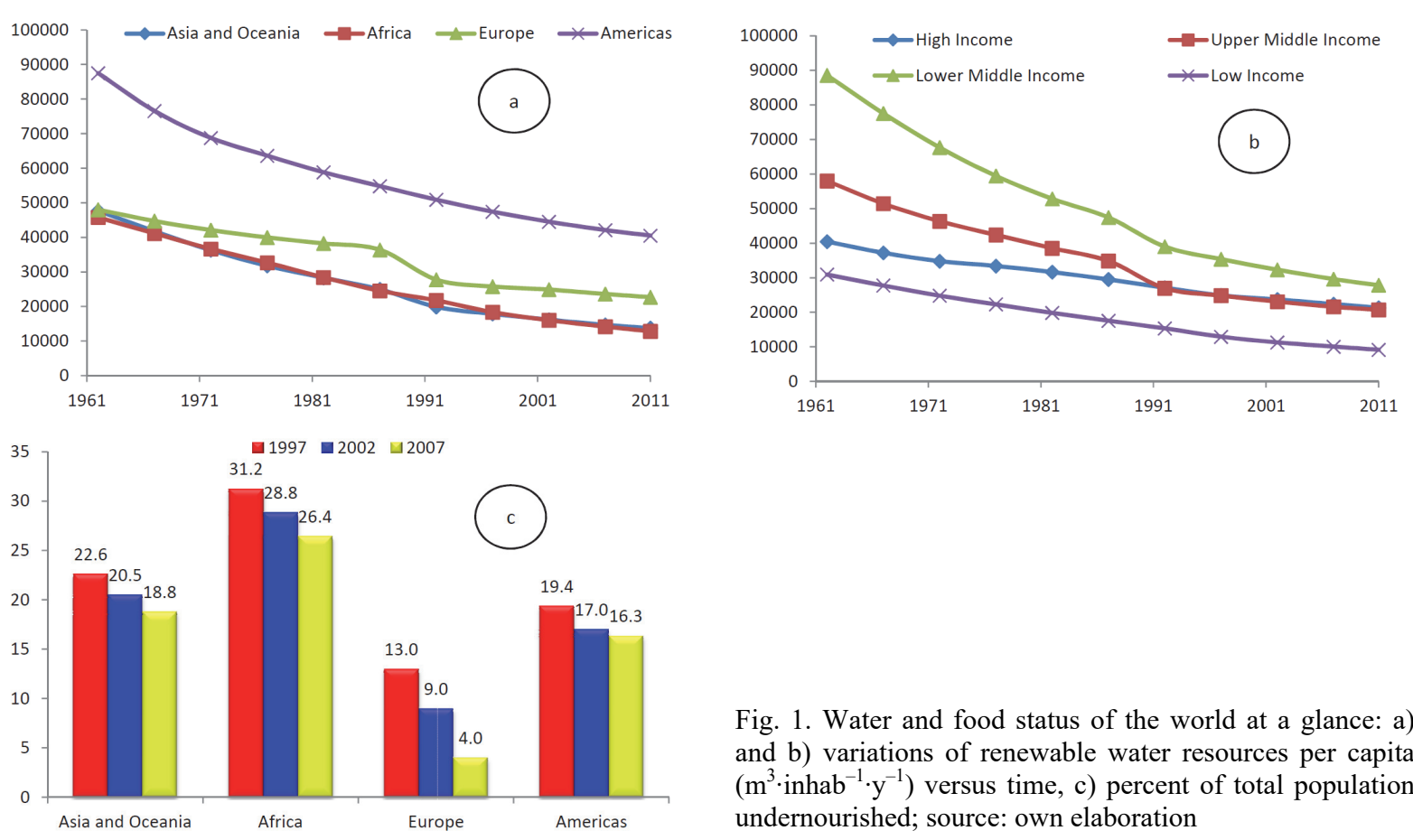

Fig. 1. Water and food status of the world at a glance: a) and $b$ ) variations of renewable water resources per capita $\left(\mathrm{m}^{3} \cdot\right.$ inhab $\left.^{-1} \cdot \mathrm{y}^{-1}\right)$ versus time, $\left.\mathrm{c}\right)$ percent of total population undernourished; source: own elaboration
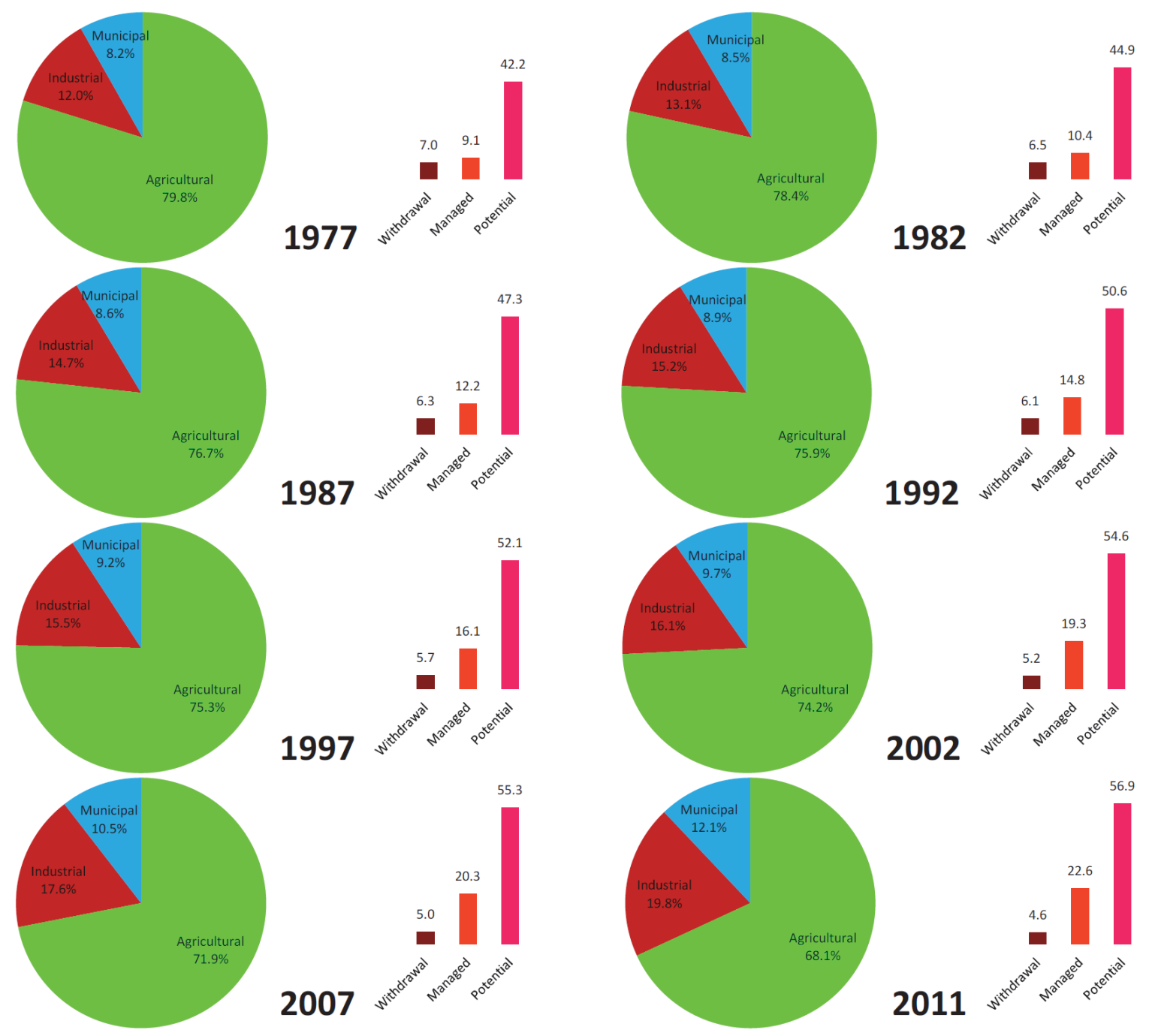

Fig. 2. Status of renewable water resources and agricultural water management in the previous half of century; source: own study 
South America and North Africa and it is about 30\% for Central America and the Caribbean, Eastern Europe, and Sub-Saharan Africa [FAO 2012].

Therefore, studying agricultural water management due to its role on renewable water resources is still reasonable in the world.

The different aspects of irrigation in agricultural water management, such as irrigation efficiency [VALIPOUR, MONTAZAR 2012], soil salinity [DU PLESSIS 1985], water-saving [MONTENEGRO et al. 2010; VALIPOUR 2016a, b, c], sustainable development [VALIPOUR 2014a, b; VALIPOUR 2017; VALIPOUR et al. 2012; YANNOPOULOS et al. 2015], soil water management [STEINER, KELLER 1992], evapotranspiration [MCCREADY, DUKES 2009; VALIPOUR 2014a, b; 2015a, b, c, d, e, f, g, h, i; VALIPOUR, ESLAMIAN 2014; VALIPOUR et al. 2017a, b; VALIPOUR, GHOLAMI SEFIDKOUHI 2017] and crop yield [WU et al. 2013] have been investigated in previous works. TURRAL et al. [2010] showed that investment is one of the most effective factors on area equipped for irrigation to 2050. NEUMAN et al. [2011] cited that area equipped for irrigation to be expanded by 40 million ha, by 2030. PLUSQUELLEC [2002] claimed that area equipped for irrigation would be increased by $15 \%$ to $22 \%$ for 2025 . KNOX et al. [2012] claimed demonstrating efficient or 'best' use of water is not straightforward in England, but farmers and the water regulator needed a rational approach that reflects the needs of the farming community whilst providing a policy framework for protecting the environment. NAMARA et al. [2010] mentioned role the of agricultural water management to reduce poverty in the world as three pathways. Those are improvement of production, enhancement of employment opportunities and stabilization of income and consumption using access to reliable water, increasing high-value products, and finally its role to nutritional status, health, societal equity and environment. They preferred improving the management of existing systems as a selected strategy in Asia. VALIPOUR [2013a, b, c, d, e] mentioned the status of irrigated and rainfed agriculture in the world, summarized the advantages and disadvantages of irrigation systems, and attended to update of irrigation information to choose an optimum decision. His results showed that $46 \%$ of cultivated areas in the world are not suitable for rainfed agriculture because of climate changes and other meteorological conditions. FRANKS et al. [2008] studied developing capacity for agricultural water management in current practice and future directions. They suggested increased attention to monitoring and evaluation of capacity development, and closer links to emerging work on water governance. FERREYRA et al. [2008] concluded that, instead of forcing watershed-based governance structures, the exploration and examination of more creative and flexible ways of linking watershed imperatives to existing socially and politically meaningful scales in agricultural areas of Ontario and elsewhere was warranted. DE LoE et al. [2001] studied agricul- tural water use in Ontario. They have claimed that future water allocation decisions must take account of the distribution of agricultural water withdrawals, especially those for irrigation, which are strongly seasonal. The previous researches are about a limited area and cannot apply them to other regions or did not consider role of all important indices for estimation of agricultural water management and the value of pressure on renewable water resources. Thus, the goal of this study is an estimation of pressure on renewable water resources by irrigation using to establish a link for more important parameters in agricultural water management based on available data in the world.

\section{METHODS}

Many variables are required to obtain the amount of area equipped for irrigation to cultivated area for cropping pattern design, macroeconomic decisions, and allocation of water resources. However, we cannot consider all parameters due to lack of adequate data. In this study, using AQUASTAT database [FAO 2013], 10 main indices were selected to assessment of agricultural water management in the world and values of them were checked using WBG database [WBG 2013]. Then, values of area equipped for irrigation and pressure on renewable water resources by irrigation were estimated in 2035 and 2060 using three different scenarios.

\section{ESTIMATION OF EQUIPPED AREA AND ITS PRESSURE ON RENEWABLE WATER RESOURCES IN 2035 AND 2060}

To estimate area equipped for irrigation in 2035 and 2060, in the first step, the author studied variations of the main indices during the past half of century using linear regression and $R^{2}$ value, then the amount of each index was estimated in 2035 and 2060 by obtained equations and three different scenarios. In the first scenario (scenario I), the author assumed that the values of the main indices would be changed by the same slope of the past half of century (Fig. 3a). However, changes of the indices show that rate of increase or decrease has been reduced in the current years. Hence, in the second (scenario II) and third (scenario III) scenarios, the author assumed that the slopes would be decreased by $30 \%$ and $50 \%$ respectively. Therefore new values of the indices (in 2035 and 2060) were computed using these new slopes. In the second step, variations of area equipped for irrigation versus the other main indices were surveyed and a linear equation with related $R^{2}$ was computed for each index. In the next step, values of area equipped for irrigation (for each index and each scenario) were determined using replacement of obtained values for each index in 2035 and 2060 (the first step) in linear equation of the second step. Finally, a relationship has been established between calculated data (for area equipped for irrigation) as: 

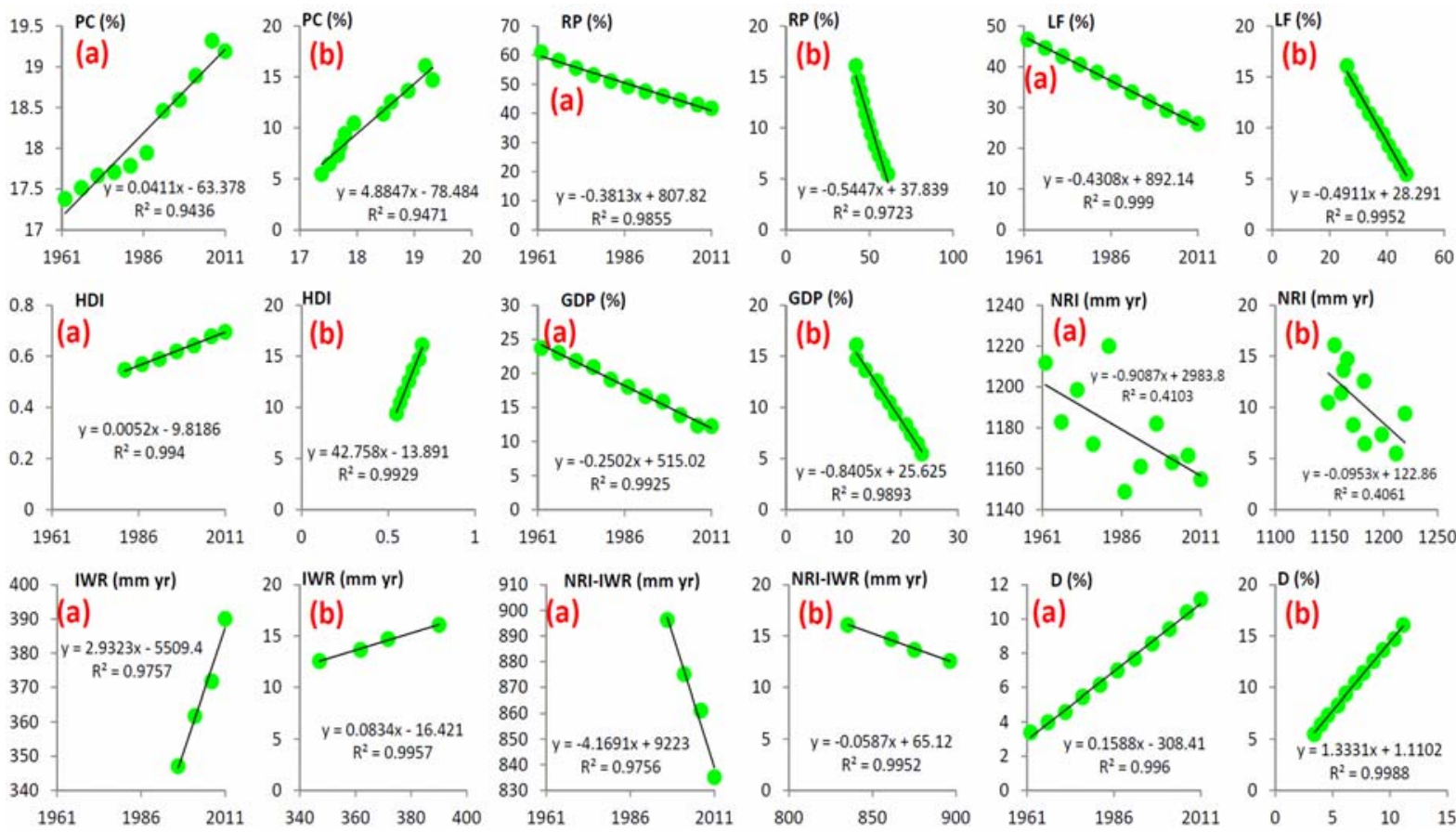

Fig. 3. Variations of the main indices versus time and area equipped for irrigation: (a) horizontal axes are time (year) and vertical axes are the indices and (b) horizontal axes are the indices and vertical axes are area equipped for irrigation (\%),

value of $x$ in (b) is equal to value of $y$ in (a); $P C=$ permanent crops to cultivated area; $R P=$ rural population to total population; $L F=$ labour force = total economically active population in agriculture to total economically active population;

$H D I=$ human development index; $G D P=$ value added to gross domestic product by agriculture; $N R I=$ national rainfall

index; $I W R=$ irrigation water requirement; $D=$ percent of total cultivated area drained; $N R I-I W R=$ the difference between $N R I$ and $I W R$; source: own study

$$
I_{10}=\frac{\sum\left(y R^{2}\right)}{\sum R^{2}}
$$

where, $y$ is obtained value for area equipped for irrigation in the second step (Fig. 3b) and values of $R^{2}$ showed in the Figs $3 b$. Finally, pressure on renewable water resources by irrigation estimates using trend between renewable water resources and equipped area.

\section{EVALUATION OF THE MAIN INDICES OF AGRICULTURAL WATER MANAGEMENT IN THE PAST HALF OF THE CENTURY}

Figure 3 shows variations of the main indices versus time and area equipped for irrigation. According to the Figure $3 \mathrm{a}$ values of permanent crops to cultivated area, $H D I$, irrigation water requirement, and percent of total cultivated area drained have been increased and values of rural population to total population, economically active population in agriculture, value added to $G D P$ by agriculture, and the difference between $N R I$ and irrigation water requirement have been decreased in the previous half of the century. Thus, role of permanent crops to cultivated area, HDI, irrigation water requirement, and percent of total cultivated area drained is increasing for area equipped for irrigation and it is decreasing for the other indices (Fig. 3b). In addition, a significant change is observable in the middle of 1980s for permanent crops to cultivated area. Although more values of this index can be helped to better scheduling for allocation of required water, it is dependent to climate conditions [DE SALVo et al. 2013; VALIPOUR 2012a, b, c, d], tendency of farmers [BOLLIGER et al. 2006], and government's policy [SUKHWAL 1991]. Previous researches show the advantages of rural development on agricultural water management and sustainable agriculture [EVANS et al. 2012]. Effect of proper labour force on water management and improvement of sustainable agriculture has been studied in a lot of researches [NAIKEN, SCHULTE 1976]. However, slope of reduction of rural population to total population and total economically active population in agriculture to total economically active population is more than increasing slope of $H D I$ in the world. It is a big warning [HUSSAIN 2007] because although mechanization and use of new technologies have an important role in the enhancement of agricultural knowledge and increasing productivity [KIRPICH et al. 1999], labour force has a vital and irreplaceable role in agricultural scheduling and macroeconomic perspectives [HENDRICKSON et al. 2008]. The HDI index as a weighted measure of the Falkenmark indicator [FALKENMARK 1989] in order to account for the ability to adapt to water stress is termed the Social Water Stress Index.

According to the Fig. 3a, the value of NRI is variable during the past half of century due to many different factors such as greenhouse gases [LAL 2001], global warming [MiCHAELS 1990], climate change 
[MUZIK 2002] etc. and linear regression is not suitable for evaluation of its trend.

Thus, there is not a significant trend between variations of $N R I$ and area equipped for irrigation (Fig. $3 \mathrm{~b})$. Due to the mentioned cases, the role of this index has not been considered in estimation of area equipped for irrigation in 2035 and 2060.

After GOMMES and PETRASSI [1994], this index was known as a considerable factor in drought studies [MishrA, SingH 2010]. Variation of irrigation water management can be effected on river basin management [SIMENSTAD et al. 1992], water allocation policy and agricultural expansion.

The difference between $N R I$ and irrigation water requirement is known as water deficit and the regions with negative values of that have a critical status for water resources management [HUSSAIN et al. 2007].

Previous studies notify influence of drainage on subirrigation [VALERO et al. 2007], crop productivity [ALE et al. 2009], improving water management [AYARS et al. 2006], and water balance [ALE et al. 2010].
ESTIMATION OF AREA EQUIPPED

FOR IRRIGATION TO CULTIVATED AREA

AND ITS PRESSURE ON RENEWABLE WATER

RESOURCES USING THE OTHER MAIN INDICES

OF AGRICULTURAL WATER MANAGEMENT

According to the Table 1, if the current decreasing trend continues, we will meet the world without value added to GDP by agriculture in the future. In addition, decreasing slope for rural population to total population and labour force is warning. In the Table 1 , the minimum value for equipped area is related to HDI $(16.1 \%$ in the scenario III by 2035$)$ and the maximum value is related to irrigation water requirement and difference between NRI and irrigation water requirement (27.9\% the scenario I by 2060). The similar values show that all selected indices are important and their selection is reasonable to study of agricultural water management and estimation of area equipped for irrigation in the future. In the Table 2, values of pressure on the renewable water resources by irrigation that estimated using Figure 4 have been presented.

Table 1. Estimated values for the main indices (PC, RP, LF, HDI, GPD, IWR, D and NRI-IWR)

\begin{tabular}{|c|c|c|c|c|c|c|c|c|c|c|c|c|}
\hline \multirow{3}{*}{ Parameter } & \multicolumn{4}{|c|}{ Scenario I } & \multicolumn{4}{|c|}{ Scenario II } & \multicolumn{4}{|c|}{ Scenario III } \\
\hline & \multicolumn{2}{|c|}{2035} & \multicolumn{2}{|c|}{2060} & \multicolumn{2}{|c|}{2035} & \multicolumn{2}{|c|}{2060} & \multicolumn{2}{|c|}{2035} & \multicolumn{2}{|c|}{2060} \\
\hline & $\mathrm{a}$ & $\mathrm{b}$ & $\mathrm{a}$ & $\mathrm{b}$ & $\mathrm{a}$ & $\mathrm{b}$ & $\mathrm{a}$ & $\mathrm{b}$ & $\mathrm{a}$ & $\mathrm{b}$ & $\mathrm{a}$ & $\mathrm{b}$ \\
\hline$P C, \%$ & 20.3 & 20.5 & 21.3 & 25.5 & 20.0 & 19.0 & 20.7 & 22.6 & 19.8 & 18.1 & 20.3 & 20.6 \\
\hline$R P, \%$ & 31.9 & 20.5 & 22.3 & 25.7 & 34.6 & 19.0 & 27.9 & 22.6 & 36.5 & 18.0 & 31.7 & 20.6 \\
\hline$L F, \%$ & 15.5 & 20.7 & 4.7 & 26.0 & 18.6 & 19.2 & 11.0 & 22.9 & 20.6 & 18.2 & 15.2 & 20.8 \\
\hline$H D I$ & 0.763 & 18.8 & 0.893 & 24.3 & 0.726 & 17.1 & 0.817 & 21.0 & 0.701 & 16.1 & 0.766 & 18.9 \\
\hline$G D P, \%$ & 5.9 & 20.7 & 0.0 & 25.6 & 7.7 & 19.2 & 3.3 & 22.9 & 8.9 & 18.2 & 5.7 & 20.8 \\
\hline$I W R, \mathrm{~mm} \cdot \mathrm{yr}^{-1}$ & 457.8 & 21.8 & 531.1 & 27.9 & 436.7 & 20.0 & 488.0 & 24.3 & 422.6 & 18.8 & 459.3 & 21.9 \\
\hline$N R I-I W R, \mathrm{~mm} \cdot \mathrm{yr}^{-1}$ & 738.9 & 21.7 & 634.7 & 27.9 & 768.9 & 20.0 & 695.9 & 24.3 & 788.9 & 18.8 & 736.8 & 21.9 \\
\hline$D, \%$ & 14.7 & 20.8 & 18.7 & 26.1 & 13.6 & 19.2 & 16.4 & 23.0 & 12.8 & 18.2 & 14.8 & 20.9 \\
\hline
\end{tabular}

Explanations: $P C, R P, L F, H D I, G P D, I W R, N R I-I W R, D$ as at Fig. 3a; a estimated using the equations related to the Figs $3 a$, b estimated using the equations related to the Figs $3 \mathrm{~b}$.

Source: own study.

Table 2. Estimated values for area equipped for irrigation and pressure on renewable water resources by irrigation

\begin{tabular}{|c|c|c|c|c|c|c|}
\hline \multirow{2}{*}{$\begin{array}{c}\text { State in } \\
\text { year } 2011\end{array}$} & Scenario I & \multicolumn{2}{c|}{ Scenario II } & \multicolumn{1}{c|}{ Scenario III } \\
\cline { 2 - 6 } & 2035 & 2060 & 2035 & 2060 & 2035 & 2060 \\
\hline \multicolumn{7}{|c|}{ Area equipped for irrigation, \% } \\
\hline 16 & 20.7 & 26.1 & 19.1 & 22.9 & 18.0 & 20.8 \\
\hline \multicolumn{7}{|c|}{ Pressure on renewable water resources, \% } \\
\hline 5.5 & 7.1 & 9.2 & 6.5 & 8.0 & 6.1 & 7.2 \\
\hline
\end{tabular}

Source: own study.

As seen in the Table 2, the minimum change related to the scenario III by $2035(11.4 \%)$ and the maximum change related to the first scenario by 2060 $(66.6 \%)$. Thus, pressure on renewable water resources will increase in the future and it can be considered in many different sections. As shown in the Figure 5, percent of area equipped for irrigation by surface water has been increased and instead percents of area equipped for irrigation by groundwater and mixed surface water and groundwater have been increased.

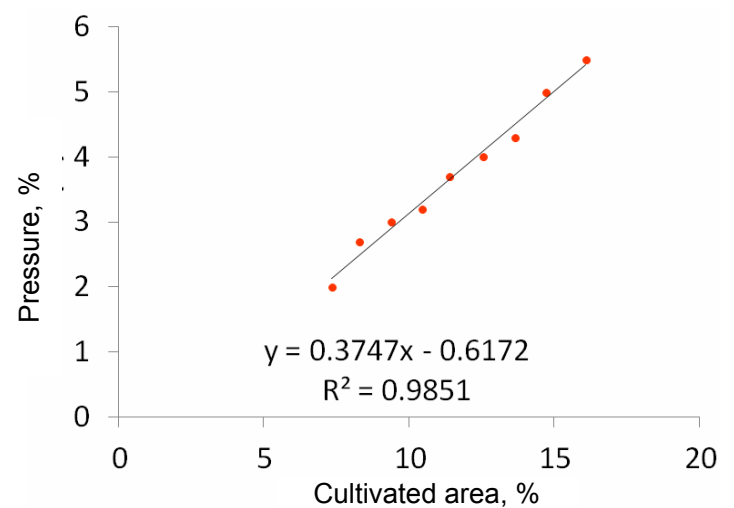

Fig. 4. Trend between pressures on renewable water resources by irrigation versus area equipped for irrigation to cultivated area in the previous half of century; source: own study

These lead to increase of pump stations to extraction of groundwater. In other hand, the tendency to pressurized irrigation systems due to their advantages 


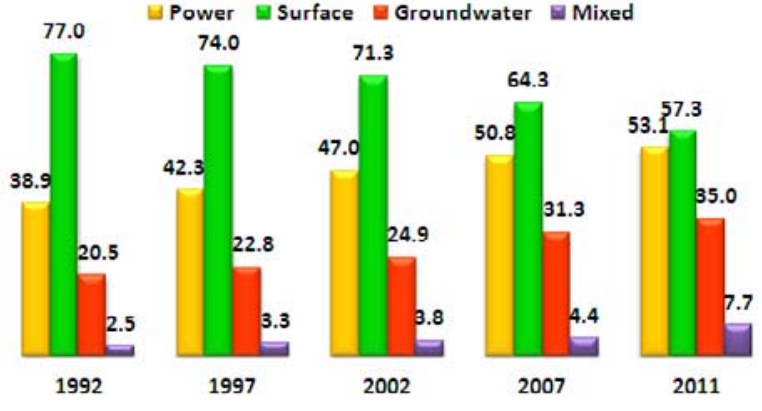

Fig. 5. Pressure on water resources in the previous two decades, surface indicates percent of area equipped for irrigation by surface water (\%), groundwater indicates percent of area equipped for irrigation by groundwater (\%), mixed indicates percent of area equipped for irrigation by mixed surface water and groundwater (\%), power indicates percent of area equipped for irrigation power irrigated (\%); source: own study

increases the need to electrical energy. Hence, percent of power irrigation has been increased (Fig. 5). So, estimation of area equipped for irrigation can be helped not only for estimation of its pressure on renewable water resources but also for the study of many different aspects of its impact on the science involved with irrigation and water resources. Although we can estimate area pressure on renewable water resources for after 2060 , but it is advised that we update our information every year, every decade, or at least every half of the century.

\section{CONCLUSION}

Results showed that trend of permanent crops to cultivated area, human development index (HDI), irrigation water requirement, and percent of total cultivated area drained is increasing and trend of rural population to total population, total economically active population in agriculture to total economically active population, value added to $G D P$ by agriculture, and the difference between $N R I$ and irrigation water requirement is decreasing. The minimum and maximum values of pressure on renewable water resources by irrigation, are related to the third and first scenarios by $2035(6.1 \%)$ and 2060 (9.2\%), respectively.

\section{REFERENCES}

Ale S. Bowling L.C., Brouder S.M., Frankenberger J.R., YousSEF M.A. 2009. Simulated effect of drainage water management operational strategy on hydrology and crop yield for Drummer soil in the Midwestern United States. Agricultural Water Management. Vol. 96 p. 653-665.

Ale S., Bowling L.C., Owens P.R., Brouder S.M., FranKENBERGER J.R. 2010. Development and application of a distributed modeling approach to assess the watershed-scale impact of drainage water management. Agricultural Water Management. Vol. 107 p. 23-33.

Ayars J.E., Christen E.W., Hornbuckle J.W. 2006. Controlled drainage for improved water management in arid regions irrigated agriculture. Agricultural Water Management. Vol. 86 p. 128-139.

Bolliger A., Magid J., Amado J.C.T., Neto F.S., de Fatima dos Santos Ribeiro M., Calegari A., Ralisch R., DE NeERgaARD A. 2006. Taking stock of the Brazilian "Zero Till Revolution": A Review of Landmark Research and Farmers' Practice. Advances in Agronomy. Vol. 91 p. 47-110.

De Loe R., KREUtZwiser R., IVEY J. 2001. Agricultural water use in Ontario. Canadian Water Resources Journal. Vol. 26 p. 17-42.

De Salvo M., Raffaelli R., Moser R. 2013. The impact of climate change on permanent crops in an Alpine region: A Ricardian analysis. Agricultural Systems. Vol. 118 p. 23-32.

Du PLESSIS H.M. 1985. Evapotranspiration of citrus as affected by soil water deficit and soil salinity. Irrigation Science. Vol. 6 p. 51-61.

Evans A.E.V., Giordano M., Clayton T. (eds) 2012. Investing in agricultural water management to benefit smallholder farmers in Ethiopia. AgWater Solutions Project country synthesis report. Colombo, Sri Lanka. International Water Management Institute (IWMI). IWMI Working Paper. No. 152 pp. 35. DOI: org/10. $5337 / 2012.215$

FALKENMARK M. 1989. The massive water scarcity threatening Europe - why isn't it being addressed. Ambio. Vol. 18 p. 112-118.

FAO 2012. The state of food and agriculture. Rome. ISSN 0081-4539 pp. 165.

FAO 2013. AQUASTAT database [online]. [Access 25.10. 2013]. Available at: http://fao.org/nr/water/aquastat/ data/query/index.html?lang=en

Ferreyra C., De Loe R.C., KreutZWiser R.D. 2008. Imagined communities, contested watersheds: Challenges to integrated water resources management in agricultural areas. Journal of Rural Studies. Vol. 24 p. 304-321.

Franks T., Garces-Restrepo C., Putuhena F. 2008. Developing capacity for agricultural water management: current practice and future directions. Irrigation and Drainage. Vol. 57 p. 255-267.

Gommes R., Petrassi F. 1994. Rainfall variability and drought in Sub-Saharan Europe since 1960. Agrometeorology Series Working Paper. No. 9. Rome, Italy. FAO pp. 7.

HENDRICKSON M.K., JAMES JR H.S., HEFFERNAN W.D. 2008. Does the world need U.S. farmers even if the world don't? Journal of Agricultural and Environmental Ethics. Vol. 21 p. 311-328.

HUSSAIN I. 2007. Pro-poor intervention strategies in irrigated agriculture in Asia: Issues, lessons, options and guidelines. Irrigation and Drainage. Vol. 56 p. 119-126.

Hussain I., Turral H., Molden D., AhMad M.D. 2007. Measuring and enhancing the value of agricultural water in irrigated river basins. Irrigation Science. Vol. 25 p. $263-282$.

KILLGORE M. 2009. Recent developments in water policy in the world. World Environmental and Water Resources Congress p. 1-8.

Kirpich P., HAMAN D., STYles S. 1999. Problems of irrigation in developing regions. Journal of Irrigation and Drainage Engineering. Vol. 125 p. 1-6.

KnOX J.W., KAY M.G., WeAtherheAd E.K. 2012. Water regulation, crop production, and agricultural water management - Understanding farmer perspectives on irrigation efficiency. Agricultural Water Management. Vol. 108 p. 3-8. 
LAL R. 2001. Potential of desertification control to sequester carbon and mitigate the greenhouse effect. Climate Changes. Vol. 51 p. 35-72.

MCCREAdY M., DuKeS M. 2009. Evaluation of irrigation scheduling efficiency and adequacy by various control technologies compared to theoretical irrigation requirement. World Environmental and Water Resources Congress 1-19.

MiChAELS P.J. 1990. The greenhouse effect and global change: Review and reappraisal. International Journal of Environmental Studies. Vol. 36 p. 55-71.

Mishra A.K., SingH V.P. 2010. A review of drought concepts. Journal of Hydrology. Vol. 391 p. 202-216.

Montenegro S.G., Montenegro A., Ragab R. 2010. Improving agricultural water management in the semi-arid region of Brazil: Experimental and modelling study. Irrigation Science. Vol. 28 p. 301-316.

MUZIK I. 2002. A first-order analysis of the climate change effect on flood frequencies in a subalpine watershed by means of a hydrological rainfall-runoff model. Journal of Hydrology. Vol. 267 p. 65-73.

NAiKen L., Schulte W. 1976. Population and labour force projections for agricultural planning. Food Policy. Vol. 1 p. 192-202.

NAmara R., Munri E., Hanjra A., Castillo G.E., Ravnborg H.M., Smith L., van Koppen B. 2010. Agricultural water management and poverty linkages. Agricultural Water Management. Vol. 97 p. 520-527.

Neumann K., Stehfest E., Verburg P.H., Siebert S., Muller C., VeldKAMP T. 2011. Exploring global irrigation patterns: A multilevel modelling approach. Agricultural Systems. Vol. 104 p. 703-713.

PLUSQUELLEC H. 2002. Is the daunting challenge of irrigation achievable? Irrigation and Drainage. Vol. $51 \mathrm{p}$. 185-198.

Simenstad C.A., JAY D.A., SHERwoOd C.R. 1992. Impacts of watershed management on land-margin ecosystems: The Columbia River estuary. In: Watershed management. Balancing sustainability and environmental change Watershed Management. Ed. R. Naiman. Springer p. 266-306.

STEINER R., KELLER A. 1992. Irrigation land management model. Journal of Irrigation and Drainage Engineering. Vol. 118 p. $928-942$.

SuKHWAL B.L. 1991. Native the world water rights in the water scarce Western United States, its causes, consequences and probable solutions. GeoJournal. Vol. 24 p. 347-354.

TurRal H., Svendsen M., Faures J.M. 2010. Investing in irrigation: Reviewing the past and looking to the future. Agricultural Water Management. Vol. 97 p. 551-560.

VAlero C.S., Madramootoo C.A., Stampfli N. 2007. Water table management impacts on phosphorus loads in tile drainage. Agricultural Water Management. Vol. 89 p. $71-80$.

VALIPOUR M. 2012a. A comparison between horizontal and vertical drainage systems (include pipe drainage, open ditch drainage, and pumped wells) in anisotropic soils. IOSR Journal of Mechanical and Civil Engineering. Vol. 4. Iss. 1 p. 7-12. DOI: org/10.9790/1684-0410712.

VALIPOUR M. 2012b. Ability of Box-Jenkins models to estimate of reference potential evapotranspiration (A case study: Mehrabad Synoptic Station, Tehran, Iran). IOSR Journal of Agriculture and Veterinary Science (IOSRJAVS). Vol. 1. Iss. 5 p. 1-11. DOI: org/10.9790/23800150111.
VALIPOUR M. 2012c. Hydro-module determination for Vanaei village in Eslam Abad Gharb, Iran. ARPN Journal of Agricultural and Biological Science. Vol. 7. Iss. 12 p. $968-976$.

VALIPOUR M. 2012d. Number of required observation data for rainfall forecasting according to the climate conditions. American Journal of Scientific Research. Vol. 74 p. $79-86$.

VALIPOUR M. 2012e. Critical Areas of Iran for Agriculture Water Management According to the Annual Rainfall. European Journal of Scientific Research. Vol. 84. Iss. 4 p. $600-608$.

VALIPOUR M. 2013a. Evolution of irrigation-equipped areas as share of cultivated areas. Irrigation and Drainage Systems Engineering. Vol. 2. 1, e114. DOI: 10.4172/ 2168-9768.1000e114.

VALIPOUR M. 2013b. Increasing irrigation efficiency by management strategies: Cutback and surge irrigation. ARPN Journal of Agricultural and Biological Science. Vol. 8. Iss. 1 p. 35-43.

VALIPOUR M. 2013c. Necessity of irrigated and rainfed agriculture in the world [online]. Irrigation and Drainage Systems Engineering. S9, e001. [Access 23.10.2013]. Available at: http://omicsgroup.org/journals/necessityof-irrigated-and-rainfed-agriculture-in-the-world-21689768.S9-e001.php?aid=12800

VALIPOUR M. 2013d. Use of surface water supply index to assessing of water resources management in Colorado and Oregon, US [online]. Advances in Agriculture, Sciences and Engineering Research. Vol. 3. Iss. 2 p. 631640. [Access 22.10.2013]. Available at: http://valipour.webs.com/13.pdf

VALIPOUR M. 2014a. Application of new mass transfer formulae for computation of evapotranspiration. Journal of Applied Water Engineering and Research. Vol. 2. Iss. 1 p. $33-46$.

VALIPOUR M. 2014b. Use of average data of 181 synoptic stations for estimation of reference crop evapotranspiration by temperature-based methods. Water Resources Management. Vol. 28. Iss. 12 p. 4237-4255.

VALIPOUR M. 2015a. Analysis of potential evapotranspiration using limited weather data. Applied Water Science. In Press. DOI: org/10.1007/s13201-014-0234-2.

VALIPOUR M. 2015b. Calibration of mass transfer-based models to predict reference crop evapotranspiration. Applied Water Science p. 1-11. DOI: 10.1007/ s13201015-0274-2.

VALIPOUR M. 2015c. Evaluation of radiation methods to study potential evapotranspiration of 31 provinces. Meteorology and Atmospheric Physics. Vol. 127. Iss. 3 p. 289-303.

VALIPOUR M. 2015d. Future of agricultural water management in Africa. Archives of Agronomy and Soil Science. Vol. 61. Iss. 7 p. 907-927.

VALIPOUR M. 2015e. Importance of solar radiation, temperature, relative humidity, and wind speed for calculation of reference evapotranspiration. Archives of Agronomy and Soil Science. Vol. 61. Iss. 2 p. 239-255.

VALIPOUR, M., 2015f. Investigation of Valiantzas' evapotranspiration equation in Iran. Theoretical and Applied Climatology. Vol. 121. Iss. 1-2 p. 267-278.

VALIPOUR M. 2015g. Land use policy and agricultural water management of the previous half of century in Africa. Applied Water Science. Vol. 5. Iss. 4 p. 367-395.

VALIPOUR M. 2015h. Long-term runoff study using SARIMA and ARIMA models in the United States. Meteorological Applications. Vol. 22. Iss. 3 p. 592-598. 
VALIPOUR M. 2015i. Study of different climatic conditions to assess the role of solar radiation in reference crop evapotranspiration equations. Archives of Agronomy and Soil Science. Vol. 61. Iss. 5 p. 679-694.

VALIPOUR M. 2015j. Temperature analysis of reference evapotranspiration models. Meteorological Applications. Vol. 22. Iss. 3 p. 385-394.

VALIPOUR M. 2016a. How do different factors impact agricultural water management? Open Agriculture. Vol. 1. Iss. 1 p. 89-111.

VALIPOUR M. 2016b. How much meteorological information is necessary to achieve reliable accuracy for rainfall estimations? Agriculture. Vol. 6. Iss. 4, 53. DOI: 10.3390/agriculture6040053.

VALIPOUR M. 2016c. Variations of land use and irrigation for next decades under different scenarios. Irriga. Vol. 1. Iss. 1 p. $262-288$.

VALIPOUR M. 2017. Status of land use change and irrigation in Europe by 2035 and 2060. Journal of Water and Land Development. In Press.

VAlipour M., Eslamian S. 2014. Analysis of potential evapotranspiration using 11 modified temperature-based models. International Journal of Hydrology Science and Technology. Vol. 4. Iss. 3 p. 192-207.

VAliPOUR M., GHOLAMi SEFIDKOUHI M.A. 2017. Temporal analysis of reference evapotranspiration to detect variation factors. International Journal of Global Warming. In Press. https://doi.org/10.1504/IJGW.2018.10002058
Valipour M., Gholami Sefidkouhi M.A., Khoshravesh M. 2017a. Estimation and trend evaluation of reference evapotranspiration in a humid region. Italian Journal of Agrometeorology. In Press.

VAlipour M., GhOlami Sefidkouhi M.A., Raeini-Sarjaz M. 2017b. Selecting the best model to estimate potential evapotranspiration with respect to climate change and magnitudes of extreme events. Agricultural Water Management. Vol. 180 DOI: org/10.1016/j.agwat.2016.08. 025 p. 50-60.

VAliPOUR M., MONTAZAR A.A. 2012. An evaluation of SWDC and WinSRFR Models to optimize of infiltration parameters in furrow irrigation. American Journal of Scientific Research. Vol. 69 p. 128-142.

Valipour M., Mousavi, S.M., Valipour R., Rezaei E. 2012. A New Approach for Environmental Crises and its Solutions by Computer Modeling. The 1st International Conference on Environmental Crises and its Solutions, Kish Island, Iran. [Access 30 November, 2013].

WBG 2013. WBG database [online]. [Access 20.10.2013]. Available at: http://www.worldbank.org/

WU I.P., BARRAGAN J., BRALTS V. 2013. Irrigation systems: Water conservation. Encyclopedia of Environmental Management. Taylor \& Francis. DOI: org/10.1081/EEEM-120010068

YANNOPOUlos S.I., Lyberatos G., Theodossiou N., Li W., VAlipour M., TAMBURrino A., ANGelaKis A.N. 2015. Evolution of water lifting devices (pumps) over the centuries worldwide. Water. Vol.7. Iss. 9 p. 5031-5060.

\section{Mohammad VALIPOUR}

\section{Globalne doświadczenie w zarządzaniu nawodnieniami z różnymi scenariuszami}

\section{STRESZCZENIE}

Celem badań była ocena doświadczenia w zarządzaniu wodą w rolnictwie z różnymi scenariuszami. Zaobserwowano rosnący trend trwałych upraw na obszarach rolniczych, zwiększenie indeksu rozwoju społecznego (HDI - ang. human development index), zapotrzebowania na wodę do nawodnień i udziału drenowanych obszarów rolniczych oraz malejący trend udziału ludności wiejskiej, udziału ludności gospodarczo zaangażowanej w rolnictwie w stosunku do całkowitej liczby ludności aktywnej zawodowo, zwiększenie udziału w gospodarce wartości dodanej brutto w rolnictwie oraz zwiększenie różnicy między wskaźnikiem opadu (NRI - ang. national rainfall index) a zapotrzebowaniem na wodę do nawodnień. Powierzchnię do nawodnień planowaną na lata 2035 i 2060 r. oszacowano według trzech scenariuszy: I - wartości głównych wskaźników będą zmieniały się w taki sam sposób przez pół wieku, II i III - zmniejszenie wskaźników będzie następowało odpowiednio z nachyleniem 30 i $50 \%$. Minimalne i maksymalne wartości presji nawodnień na zasoby wodne w odniesieniu do scenariusza trzeciego do 2035 r. i pierwszego do 2060 r. wynosiły odpowiednio 6,1\% i 9,2\%.

Słowa kluczowe: nawadnianie, światowe rolnictwo, woda, zrównoważone rolnictwo 